\title{
The Internationalization of Constitutional Law: A Note on the Colombian Case
}

\author{
By Manuel José Cepeda, Bogotà*
}

\section{Introduction}

The purpose of this note is that of describing the relevance of International Human Rights Law (IHRL) and International Humanitarian Law (IHL) for constitutional adjudication, entrusted in Colombia to the Constitutional Court. In order to illustrate the scope of the internationalization of Constitutional Law in Colombia I shall sketch out some especially important judgments in light of the functions played by International Law in the resolution of the constitutional controversy. Needless to say I do not intend to present an exhaustive panorama. I have preferred to present the Constitutional Court's doctrine highlighting its most significant aspects. In order to ensure the clarity of the message I want to convey, I shall emphasize its essential features, overlooking subtleties and notes on the evolution of Colombian Constitutional case-law which will surely be missed by those who know it in detail.

For those who are not familiar with the Colombian case, the statements made in this paper may sound surprising. However, it is necessary to underscore that in spite of the news about violence that abound in the foreign mass media, there actually is another Colombia, predominantly urban, in which the Rule of Law prevails. In fact, it is important to emphasize that Colombia has a long, stable and uninterrupted tradition of judicial review, since 1886. The first decision striking down a congressional act was issued in July 1887. The Supreme Court of Justice was the constitutional judge at the time and fulfilled its judicial review functions for more than a century. In 1991, the constitutional adjudication functions held by the Supreme Court were given to a newly created Constitutional Court. Since its creation, the Constitutional Court has issued more than 13.500 judgments - on average, around 850 annual judgments per year - out of which roughly $25 \%$ are adopted in exercise of abstract judicial review of legislation, and the rest in exercise of concrete judicial review of the preservation of human rights in specific cases. Abstract control is mainly triggered by an actio popularis that was created in 1910. Concrete control is triggered by a strong, informal and very fast kind of amparo, a special writ for the protection of fundamental rights named acción de tutela created in 1991. Within these figures, approximately $23 \%$ of abstract review judgments have struck down the corresponding legal provision, whereas approximately $55 \%$ of concrete review judgments have protected the relevant fundamental rights.

* LL.M.(Harvard); former Ambassador of Colombia to UNESCO and Switzerland, since 2001 Member of the Constitutional Court of Colombia, 2005/6 President of the Court. E-mail: manueljcepeda@gmail.com 


\section{The notion of "constitutionality block"}

IHRL and IHL have borne a significant impact upon constitutional adjudication. This comes as the consequence of an express decision made by the 1991 Constituent Assembly, in the sense of establishing articulation mechanisms between Constitutional Law and the International rules that are binding upon the Colombian State. Indeed, different articles of the 1991 Constitution make direct reference to IHRL and IHL, and these provisions have been interpreted broadly by the Constitutional Court. Thus, Article 9 states that the State's foreign relations are based, inter alia, on the recognition of the principles of international law accepted by Colombia; Article 93 states that the international treaties that recognize human rights and forbid their limitation during states of emergency, duly ratified by Colombia, "prevail in the internal order", and that "the rights and duties established in this Charter, shall be interpreted in accordance with the international human rights treaties ratified by Colombia". Article 44 holds that children shall enjoy the rights expressly included in the international treaties ratified by Colombia. Moreover, Article 94 states that the enunciation of rights and guarantees made in the text of the Constitution shall not be understood as an exclusion or denial of other rights which are inherent to the human person and are not included therein, and Article 214 provides that during states of emergency, the rules of International Humanitarian Law must be complied with in every aspect.

These constitutional provisions have often been invoked and applied by the Constitutional Court as sufficient grounds, in themselves, to incorporate the binding IHRL and IHL provisions into its legal reasoning. But in addition, the application of IHRL and IHL has been significantly reinforced by the jurisprudential notion of "constitutionality block". Indeed, since the early stages of its case-law, the Constitutional Court has held that the constitutional judicial review of the legal provisions and situations subject to its scrutiny must be carried out not only making reference to the actual text of the Constitution as a parameter for review, but also to a set of norms and principles that have constitutional hierarchy, even though they are not expressly included in the constitutional text, or which at least have the nature of constitutionality parameters of necessary consideration, insofar as the Constitution itself grants them special force through the above-referred reception clauses included in articles 9, 93, 94, 44 and 214. These norms as principles are incorporated into the so-called "constitutionality block", a French-inspired notion with rather specific traits in the Colombian legal system. By way of this figure, all of the provisions included in human rights treaties to which Colombia is a party, as well as the human rights provisions with a customary nature and, as a sub-chapter thereof, all the principles and rules of International Humanitarian Law, have become mandatory parameters for constitutional review in our country. This does not mean, however, that the Court carries out a "conventionality control" over the domestic legal provisions subject to its review; what it does is to carry out constitutional review, incorporating IHRL and IHL as necessary premises of its reasoning, by mandate of the Constitution itself. 
The constitutionality block includes international humanitarian norms of ius cogens. The Constitutional Court has on different occasions recognized the imperative character of these norms and their special force within the Colombian constitutional order. Thus the Court held that

"the imperative character of humanitarian norms and their integration into the constitutionality block implies that the Colombian State must adapt the norms of lesser hierarchy within its internal legal system to the contents of international humanitarian law, in order to potentiate the material realization of those values."1

More recently the Court pointed out that the essential principles of International Humanitarian Law

"have the clear rank of rules of ius cogens, given that the international community as a whole has recognized their peremptory and imperative nature, in the same way it has recognized [the peremptory nature] of basic provisions such as the prohibition of genocide, the prohibition of slavery, the prohibition of torture or the prohibition of apartheid.",

It thereafter delved into the content of three of these basic principles -the principles of distinction, precaution and humanitarian treatment - plying them as necessary guidelines to determine whether the provisions of the criminal code under review were in accordance with the constitutionality block. The Court also clarified in this last judgment that

"regardless of whether they are norms of ius cogens or not, all of the provisions of International Humanitarian Law - both substantial and procedural, both conventional and customary in origin or as general principles of law - are binding upon the Colombian State as part of the constitutionality block. They are, consequently, a parameter of necessary reference for the constitutional judge in carrying out abstract constitutional judicial review."

In interpreting the Constitutionality Block, the Court has followed a "harmonizing" approach. Thus, in applying IHRL and IHL as parameters for constitutional review, the Court has often had to refer to different applicable provisions with different degrees of protection. When harmonization cannot be reached in the case, the Court has opted for the most protective norm, based on the pro-dignity and pro-liberty interpretative principles.

\section{The functions of IHRL and IHL in constitutional adjudication}

IHRL and IHL, from their position as constitutive elements of the Constitutionality Block, have played an important role in the Colombian constitutional order. This role becomes manifest in several material functions, of which I shall highlight eight in this paper in order to illustrate the impact of the internationalization of constitutional law.

1 Decision C-225 of 1995.
Decision C-291 of 2007. 


\subsection{Definition of the scope of constitutional rights}

IHRL and IHL are sources of interpretation of the scope and limitations of constitutional rights. For example, the text of the American Convention on Human Rights, as interpreted by the Inter-American jurisprudence, has been invoked in several judgments by the Constitutional Court in order to determine the scope of fundamental rights. One of this cases referred to victims' rights. ${ }^{3}$ In the sphere of the rights of victims of crime, access to criminal justice had traditionally been construed as the possibility to report a crime and seek compensation for the damages sustained. Following the evolution of IHRL and IHL, the Constitutional Court held that access to justice comprises much more than that: the right to justice, the right to truth and the right to reparation in integrum, as pointed out by several international treaties, instruments and judicial decisions, in particular those adopted by the Inter-American Court of Human Rights. Thus the Court held that

"under International Law it has been considered insufficient for the effective protection of human rights, to grant the victims and affected parties solely compensation for damages, given that truth and justice are necessary in a society to prevent the situations that generated serious human rights violations, and also because the recognition of the intrinsic dignity and of the equal and inalienable rights of all human beings, requires that the judicial resources designed by States be oriented towards a comprehensive reparation of victims and affected parties, which comprises an economic compensation, and access to justice to know the truth about the facts and to seek, through institutional channels, the fair punishment of the perpetrators";

and that

"in International Law, as in comparative law and in our constitutional order, the rights of the victims and other persons affected by a criminal action enjoy a broad conception - not restricted exclusively to economic reparation - founded upon their rights to be treated with dignity, to participate in the decisions that affect them and to obtain effective judicial protection of the real enjoyment of their rights, inter alia, which requires authorities to guide their actions towards the comprehensive re-establishment of their rights whenever they have been violated by a crime. This is only possible if the victims and persons affected by a crime are secured, at the least, their rights to truth, justice and economic reparation of the damages sustained".

Hence victims, on the grounds of the different decisions adopted by the Court based upon IHRL and IHL, may now actively participate throughout the criminal process, in order to duly exercise their rights to justice, to truth and to reparation in integrum. 


\subsection{Identification of specific non-enumerated rights.}

A second function of IHRL and IHL is that of providing sound criteria for the identification of constitutional rights which are not expressly included within the actual text of the Constitution. This was the case, for example, of the right to personal security, which is not enunciated in the Constitution but was recognized and upheld by the Court in another well known judgment. ${ }^{4}$

In this case, the petitioners were the widow and orphaned infant child of a guerrilla who had deserted, and consequently been killed by his former partners in arms. The plaintiffs had requested protection by the Ministry of the Interior and Justice, but it was refused, given that the widow's life had not been directly threatened, nor had her son's. The Court, however, held that the Ministry was bound to make an assessment of the real type of risks faced by persons in situations that threatened their personal security, before denying the request. The right to personal security, not enumerated in the Constitution, was recognized by the Court on the grounds, inter alia, of its specific incorporation and protection in human rights treaties duly ratified by Colombia, such as the American Convention on Human Rights, expressly invoked by the Court, the International Covenant on Civil and Political Rights, the Universal Declaration of Human Rights and other relevant instruments. In this sense, it should be emphasized that the Court not only made reference to these international treaties at the moment of identifying the very existence of the right to personal security, but also transcended the general interpretation which has usually been given to the content of this right by international jurisprudence and, on the grounds of other international human rights instruments and comparative constitutional law, held that it included additional elements that provided citizens with safeguards on a wholly new range of situations that threaten their security. The following explanation by the Court sums up this interpretative process:

"the recognition and protection of the right to personal security are international obligations of the Colombian state, and therefore, this right is incorporated into our legal system by virtue of articles 93 and 94 of the Constitution. There are three international instruments binding for Colombia which include the right to personal security in their catalogue of fundamental guarantees: the Universal Declaration of Human Rights of 1948 (...), the American Convention on Human Rights (...) [and] the International Covenant on Civil and Political Rights (...). The existence of international commitments for the State with regard to the right to personal security is, thus, clear; therefore, the scope of this right in the Colombian constitutional order must be precisely determined, in light of the aforementioned instruments.

The Court notes, in the first place, that both the American Convention and the International Covenant on Civil and Political Rights include the right to personal security in 
the same article that refers to personal liberty, and that the corresponding rules enunciate aspects of due process, in particular the rules that must be observed to deprive a person of her liberty. The Chamber also notes that some international tribunals, such as the European Court of Human Rights, have interpreted the scope of a similar provision on "security" in Article 5 of the European Convention, mainly in the ambit of restrictions upon personal liberty (...). Does this mean that the Constitutional Court is bound to restrict the scope of the right to personal security to a right of defense from arbitrary state actions against liberty? The answer could only be negative. First, for a logical argument: even though the American Convention on Human Rights and the International Covenant on Civil and Political Rights enshrine the right to security in the same article that regulates personal liberty, the Universal Declaration of Human Rights, which is equally binding, upholds it alongside life and liberty, without entering into specific regulations about the situation of persons deprived of their liberty (...). On the other hand, the security of certain special categories of persons or groups, in relation to other different types of risks -even those that come from private persons, not from the State-, has been recognized and specifically protected in other international instruments approved by Colombia; thus, in the Resolution on the Elimination of All Forms of Religious Intolerance, approved by the United Nations General Assembly in 1998, States were called upon to secure, in particular, that no person within their jurisdiction be deprived from her rights to life, liberty or security by reason of her religion or beliefs; and the International Convention for the Elimination of All Forms of Racial Discrimination states, in article 5, that States Parties must eliminate all types of racebased discrimination so as to secure, inter alia, the right to personal security and State protection against violence or bodily injury (...)".

The relevance of IHRL and IHL for the adoption of this decision, coupled with reference to comparative law, is notorious. The Court thereafter ordered the security assessment required by the petitioner, and clarified that should the risk posed upon the plaintiff so require, authorities had to adopt the adequate protective measures.

\subsection{Identification of special needs and basic standards of protection. The internally displaced population case (Decision T-025 of 2004)}

Colombia has the second largest population of internally displaced persons (IDPs) in the world. The official measurement records near 2 million. An NGO and the Catholic Church report nearly 4 million in a country of 42 million inhabitants.

By the end of 2003, over one thousand families composed of persons who had been internally displaced by the armed conflict considered that their fundamental rights were being disregarded by the State, even if guerrillas and paramilitary groups were mainly responsible for their displacement, because of the authorities' omission in protecting them. The Constitutional Court, after gathering evidence on the situation of the roughly 3.5 million persons who had been internally displaced in Colombia since 1985, concluded that in 
general, they were actually living under conditions that amounted to an "unconstitutional state of affairs", partly because the basic standards of protection established in UN Guiding Principles (1998) concerning IDPs were permanently and massively being disregarded by several state agencies. Indeed, the Court made extensive recourse to the Guiding Principles, which are in part a specification of pre-existing IHRL and IHL obligations binding for the Colombian State - a point explicitly acknowledged by the Court when it stated that in the face of IDPs special needs the Guiding Principles

"compile the provisions about internal displacement of International Human Rights Law, International Humanitarian Law and -by analogy- International Refugee Law, and contribute to the interpretation of the rules that form part of this protection system". 5

Thereafter in this same judgment, the Court made reference to different specific Principles at the moment of determining the constitutional fundamental rights that were threatened or violated in situations of forced internal displacement, and the specific content acquired by those rights as a consequence of IDPS' exposure to such situations, with the corresponding State obligations. The Court enumerated the following rights, citing the specific Guiding Principles that were relevant for the interpretation of their scope once forced displacement had taken place: life, freedom to choose one's residence, free development of the personality, freedom of association and freedom of expression, family unity and family protection, health, personal integrity, personal security, freedom of circulation, work and choice of profession or occupation, food, education, dignified housing, peace, legal personality, equality the rights of specially protected categories of persons - such as children, women heads of household, persons with discapacities and elderly persons - and in general, economic, social and cultural rights.

In addition, on the grounds of this enumeration and interpretation the Court concluded that, given the multiplicity of constitutional rights affected by forced internal displacement, displaced persons have an entitlement to urgent preferential State treatment. Immediately thereafter, the Court expressly held that

"the scope of the measures that authorities are bound to adopt is determined in accordance [with] three basic parameters (...) as follows: (i) the principle of favorability in the interpretation of the provisions that protect the displaced population, (ii) the Guiding Principles on Forced Internal Displacement, and (iii) the principle of prevalence of substantial law in the context of a Social State grounded in the Rule of Law -Estado Social de Derecho- (...)". 6

Hence the Guiding Principles were held to be, not only key interpretative criteria to establish the scope of IDPs' rights, but also guidelines in determining the scope of State authori-

6

See above Nr. 5 
ties' duties and obligations in relation to IDPs, and as a consequence of the systematic and massive violation of their constitutional guarantees.

In this same judgment, the Court went further still and identified a set of minimum fundamental rights of displaced persons which were to be satisfied under any circumstance by the authorities. The Court explained in section 9 of the judgment that, given the limited resources available to the Colombian State, it is materially impossible to satisfy the entire set of IDPs' constitutional rights, which makes it necessary for the authorities to establish priority areas upon which they would focus their efforts so as to progressively advance in the guarantee of their effective enjoyment, and eventually fulfill the complete series of obligations that bind the authorities in this field; in the Court's terms,

"given the current dimension of the problem of displacement in Colombia, as well as the limited nature of the resources available to the State to comply with this goal, it must be accepted that at the moment of designing and implementing a given public policy for the protection of the displaced population, the competent authorities must carry out a balancing exercise, and establish priority areas in which timely and effective attention shall be provided to these persons. Therefore, it will not always be possible to satisfy, in a simultaneous manner and to the maximum possible level, the positive obligations imposed by all the constitutional rights of the entire displaced population, given the material restrictions at hand and the real dimensions of the evolution of the phenomenon of displacement"?

Nevertheless, the Court specifically warned that

"there exist certain minimum rights of the displaced population, which must be satisfied under all circumstances by the authorities, given that the dignified subsistence of the people in this situation depends on it.

These minimum rights, or minimum mandatory levels of satisfaction of the State's obligations towards IDPs, which include duties with a positive content that bind the authorities to materially provide the necessary goods and services, were defined by the Court taking into account the relevant international provisions, in particular their codification in the Guiding Principles, as obligatory interpretative parameters.

On these grounds, the Court imparted several complex enforcement orders to protect the rights of all IDPs -both civil and political rights, as well as social, economic and cultural rights-, it required the government to present periodic reports on how the state of unconstitutional affairs was being solved, and since then it has retained its competence to follow up the implementation of its orders. 


\subsection{Identification of minimum standards of protection}

A fourth function of IHRL and IHL is that of providing the grounds for determining the minimum levels of protection that must be fulfilled by the national legal system; the importance granted to IHRL and IHL in this sense has risen to a point where the Constitutional Court prefers IHRL or IHL over any domestic provisions or judicial doctrines with narrower or less favorable scopes of protection.

Thus, for example, the Court examined an unconstitutionality claim presented against the provision of the Criminal Code that described the elements of the crime of forced disappearance. ${ }^{8}$ The lawsuit was specifically directed against the expression in this article by which forced disappearance would only be configured whenever the perpetrator belonged to an illegal armed group. The Court struck this segment down, considering that it was contrary to article 12 of the Constitution (which protects the right to personal integrity), as interpreted in light of the Inter-American jurisprudence. In doing so, the Court broadened the possible types of perpetrators of the crime of forced disappearance - an exceptional move, given that the general jurisprudential doctrine holds that it is for the Legislator to configure the scope of application of criminal law.

In this case, the Court cited two cases decided in 1989 by the Inter-American Court of Human Rights -the Velásquez Rodríguez and Godínez Cruz cases, in which a detailed description of the crime of forced disappearance was made, pointing out that it is a crime against humanity that violates many of the rights recognized in the Convention-, and it emphasized that in the Godínez Cruz case, the Inter-American Court had clarified that on principle,

"every violation of the rights recognized by the Convention, carried out by an act of public power or of persons who act in exercise of the powers granted by their official positions, is attributable to the State".

Then the Constitutional Court cited the InterAmerican Convention on Forced Dissappearance of Persons, which also defines the crime including within its scope the acts committed by agents of the State, or by persons or groups of persons that act with the authorization, support or acquiescence of the State. The Court concluded on these grounds that the InterAmerican criteria

"constitute the minimum standard of protection on the grounds of which States must design their legislation". 9

In the light of these conclusions, the Court then proceeded to analyze the conformity of the legal provision under review with Colombia's international obligations in this field -clarifying that the relevant international legal provisions are incorporated into the Constitutionality Block by mandate of Article 93 of the Constitution-, and it concluded that a complete 
reading of the norm reveals that public officers are not excluded as possible perpetrators of the crime of forced disappearance, which is

"in accordance with the minimum level of protection established in international instruments that describe forced disappearance as a State crime",

and therefore is in accordance with the Constitutional provisions; the expression under review does disregard such international minimum, insofar as it excludes from the article's scope of application the cases of forced disappearance committed by private persons who do not form part of any group, who form part of non-armed illegal groups, or of groups that do not normally operate outside the Law. For the Court, this was tantamount to a violation of article 12 of the Constitution, which

"establishes a protection which is broader than that provided by the international instruments, according to which forced disappearance may only be committed by a State agent, a political organization or a private person with the former's authorization, tolerance or acquiescence, from which it results that the constitutional guarantee is broader than the one provided by international legislation".

The Court pointed out that with this legal achievement, Colombia was placing itself in tune with the Inter-American Court of Human Right's doctrine by which

"States' simple omission in preventing forced disappearance when it is committed by private persons, or in controlling the irregular armed groups that carry out such acts, implies that the relevant State has failed to comply with its obligation to prevent and punish those responsible for such acts, thereby deserving the corresponding sanctions".

Later the Court decided upon the constitutional complaint filed against the articles of the Criminal Code that described the crimes of genocide, torture and torture against persons protected by International Humanitarian Law. ${ }^{10}$ The plaintiff argued that the Legislator, in introducing a requirement by which the underlying acts of genocide or torture had to be "serious", had restricted the level of protection granted to the victims of these crimes by the Constitution and the international human rights treaties ratified by Colombia. The Court upheld the expression "serious" in regards to the crime of genocide, but struck it down in relation to the qualification of the physical or moral damages that had to be sustained by the victims of torture.

In order to reach that conclusion, the Court began by recalling that in Colombia, the favorability clause in the interpretation of human rights is applicable, given that it is contained in Article 4 of the San Salvador Protocol to the American Convention on Human Rights, to which Colombia is a party; by virtue of this principle, the Court explained that

"whenever the Colombian constitutional and legal provisions provide a higher scope of protection to the relevant fundamental right, they shall prevail over the text of interna- 
tional treaties, in the same manner that in their interpretation, the least restrictive interpretation for the application of the affected fundamental right shall be preferred".

Then the Court, reiterating its prior doctrine on the constitutionality block, examined the definitions of the crimes of genocide and torture established in international treaties. Thereby it concluded, on the one hand, that the adjective "serious" formed part of all conventional descriptions of the crime of genocide included in treaties binding upon Colombia - in particular those contained in the Convention for the Prevention and Punishment of the Crime of Genocide (1951) and the Rome Statute of the International Criminal Court -, for which reason it declared the corresponding expression adjusted to the Constitution, holding that

"both in these international texts and in Article 101 [of the Criminal Code] in which the expression under review is contained, reference is made to the serious nature of the damages that have to be inflicted upon the members of a group in order to constitute the crime of genocide".

On the other hand, after examining the diverse international definitions of torture, the Court noted that the American Convention on Human Rights, as opposed to other instruments, does not include the adjective "serious" within its definition of torture; consequently, in application of the pro homine interpretative principle -also developed by the Inter-American Court of Human Rights' jurisprudence-, the Court concluded that the international definition which was decisive to review the constitutionality of the Colombian Criminal Code was the one provided by the Inter-American Convention for the Prevention and Punishment of Torture, preferring this latter definition over those included in other international instruments, such as the UN Convention against Torture and the UN Declaration Against Torture. In the Court's words,

"in the present case and contrary to what was pointed out for the crime of genocide, there is a clear contradiction between the text of articles 173 and 178 of the [Colombian Criminal Code], which criminalize respectively the crimes of torture in protected person and torture, and the Inter-American Convention for the Prevention and Punishment of Torture, international instrument which, in accordance with Article 93 of the Constitution and the pro homine principle, is the one that must be taken into account in this case (...). Indeed, such international instrument, approved by Law 409 of 1997, not only excludes the expression "serious" in order to define what must be understood by torture..."

\subsection{Identification of specific prohibitions that protect rights}

In order to fight terrorism, Congress approved, among other measures of the so called National Security Act, a provision by which civilians had the duty to collaborate with authorities in the fight against this crime. By virtue of this law, in zones of conflict, civilians' obligations would be defined through executive orders. The Court struck down this 
act of Congress, holding that such a type of involvement of civilians in armed conflict ran contrary to the principle of distinction between combatants and civilians, which forms part of IHL. Thus the Court derived from IHL a specific prohibition that protects rights. ${ }^{11}$

In its reasoning, the Court made different types of reference to IHRL and IHL. In the first place, it held that by virtue of the international obligations of the Colombian State, the principle of prevalence of the general interest could not be interpreted in such a way as to give preference to the interests of the majority and collective welfare when they clash with a person's constitutional rights; and it grounded this conclusion, inter alia, on the obligations posed by IHRL:

"the foregoing doctrine, far from being a conceptual novelty of this judgment, only systematizes this Court's jurisprudence about the relation between peaceful coexistence, public order and constitutional rights, which is in turn based upon the very notion of human rights, as it has been developed by international human rights law. Indeed, in accordance with the international human rights instruments ratified by Colombia, such as the American Convention or the International Covenant on Civil and Political Rights, which form part of the constitutionality block (Art. 93 of the Constitution), States have the duty not only to respect but also to secure the human rights of all the inhabitants of their territories. It is obvious that in furtherance of this duty to guarantee [human rights], the State is in the obligation of ensuring basic public order and peaceful coexistence conditions, because lacking them, persons would be poorly suited to truly enjoy their rights. Moreover, that State duty is so important that international instruments themselves authorize State authorities, under situations of special gravity, to declare a state of emergency and limit the force of certain human rights. Nevertheless, the State duty to secure peace and order does not enable the authorities to forget their duty to respect and not violate human rights, and therefore all security policies are framed within strict respect for the limits imposed by human rights. This is clearly pointed out by the treaties that Colombia has ratified, which constitute a binding parameter for the interpretation of constitutional rights (Art. 93 of the Constitution)."

The Court then proceeded to cite the relevant provisions of the ICCPR, the American Convention, and different holdings by the Inter-American Court of Human Rights that grounded such conclusion.

Further ahead in the judgment, the Court clarified that in situations of armed conflict, the basic human rights guarantees had to be respected alongside with the provisions of International Humanitarian Law, by mandate of article 214 of the Constitution; and it pointed out that

"humanitarian norms establish minimum limits for the protection of human rights in situations of armed conflict. This means that the basic principles of International Humanitarian Law (...) establish new limits for security and defense policies”. 
In this order, the Court held that

"if International Humanitarian Law applies in Colombia, it is obvious that security and defense strategies must respect the mandates of humanitarian law, such as the principles of proportionality and distinction, inter alia. And these mandates have concrete consequences. (...) Security and defense strategies can foresee a role for private individuals. ...This means then that the aforementioned defense and security strategies may not impose such duties upon the civilian population, that they end up involving it in the armed conflict, because this would not only affect the principle of distinction derived from international humanitarian law, but it would also disregard the constitutional mandate by which the tasks of protecting sovereignty and public order correspond to the Armed Forces, and not to private persons".

\subsection{Criteria for reviewing decrees that declare states of constitutional emergency}

Before the 1991 Constitution was adopted, the decision to declare a state of constitutional emergency in order to reestablish public order -mainly the so-called "state of siege"-, was considered a political matter. Therefore, the motives invoked by the Presidential decree to declare such a state of emergency, were shielded from judicial review. After 1991, the Court has reviewed the motives invoked by the President in adopting this decision. This change of position was partly grounded upon two doctrines developed by the European Court of Human Rights and then also applied by the Inter-American Court of Human Rights, namely, the "margin of appreciation" and the "manifest error of appreciation" doctrines. Whenever the Court has found a manifest error in the appreciation of the gravity of the disturbances invoked in the motivation of the corresponding decree, it has declared the unconstitutionality of either part of the decree, or of the entire declaration of the state of emergency. As a consequence, Presidents now resort vary rarely to states of exception, marking a big transformation in the functioning of Colombian democratic institutions.

Therefore, it may be held that a sixth function of IHRL and IHL is that of providing criteria to review the constitutionality of the declarations of states of emergency, as well as of the measures adopted in the course of their duration.

In the last of those cases, the Court carried out the judicial review - in formal and substantial terms - of Decree 1837 of that same year, by which the President of the Republic declared a "state of internal commotion" in the country in order to counter the terrorist actions of illegal armed groups. ${ }^{12}$ The varied topics examined by the Court included that of the limits established in the international instruments applicable to states of emergency. With regard to the American Convention, for example, the Court highlighted the following rules: 
(i) the rule by which the restriction of those rights considered to be intangible during states of emergency is only justified "hen the requirements established in international instruments for declaring a state of emergency have been complied with", namely, a serious threat for the survival of the Nation;

(ii) the rule by which "the possibility of suspending rights and guarantees, established in the Convention and the Covenant, does not have an absolute meaning because it is solely restricted to the limitation of their full exercise" - a rule which was illustrated in its scope by reference to Advisory Opinion OC-8/87 of the Inter-American Court on Human Rights, on "Habeas Corpus in Emergency Situations".

One other aspect of this judgment is noteworthy. The Court resorted to two notions developed by regional case-law, and even by European case-law, in the ambit of human rights, in order to limit the scope of judicial review over the exercise of discretionary powers, in this case, by the President of the Republic. The first notion is that of the "margin of appreciation". The Court recognized that the Executive has a broad margin to appreciate, first, the gravity of the facts that give rise to a disruption of public order, and second, the sufficiency of the ordinary police means to address the causes of the disruption. Nonetheless, the Court warned that such a margin is not unlimited. The second notion is that of "manifest error of appreciation", which sets a limit upon the aforementioned broad margin of appreciation, in such a way that the cause invoked to justify the declaration of a state of emergency will only be struck down as unconstitutional should the Court find a manifest error of appreciation. In addition, the Court made a clear difference between facts and the valuation of facts. Both of these notions, which are related to appreciation, are located in the sphere of evaluating facts. On the contrary, they are not pertinent when it comes to prove the existence of facts. For these reasons, the Court declared that it was unconstitutional to invoke, as one of the motives to declare a state of internal commotion, the following one: "the country with the highest rates of violence ever recorded". For the Court, this fact had not been proven. It was a rhetorical statement, from which no arguments could be deduced to broaden the scope of action of exceptional powers during the state of internal commotion declared by the President.

\subsection{A ground for the constitutional enforcement of social rights}

A seventh function is that IHRL constitutes one of the foundations of the enforceability of social rights in concrete cases. Thus, the Court has referred in many cases to the provisions of the American Convention on Human Rights, and especially the San Salvador Protocol, in order to substantiate the enforceability of social, economic or cultural rights in concrete cases, by way of the acción de tutela.

For example the Court protected the rights of a blind woman in conditions of extreme poverty who had been separated from her daughter by the family welfare authorities, without having been given a chance to access rehabilitation programs or to prove her capacities 
as household provider. ${ }^{13}$ After a careful analysis of the facts of the case, grounded upon sound scientific assessments of the situation, the Court made reference to IHRL as the foremost interpretative criterion in determining the rights of persons with discapacities, such as the plaintiff. In this judgment the Court began by stating that international human rights law is a "complete, indispensable and obligatory guide for the protection of the rights of persons with discapacities", and thereafter held that there are several international instruments "in which the community of nations has stated its express will to protect with special dutifulness the rights of persons with discapacity", instruments which

"must serve as an indispensable guiding criterion for the national authorities at all levels, in complying with their constitutional duties in the field of protection of the rights of persons with discapacities".

The Court then enumerated several international treaties and instruments which pose obligations for the Colombian State in this field, and also recalled its prior judgments on the applicability of IHRL to the interpretation of these rights, highlighting "the immense importance gained by Colombia's international commitments in order to materialize the reinforced constitutional protection to which persons with discapacities are entitled". It consequently stated that it would carefully follow -as it did- the guidelines provided by the "Uniform Rules on Equality of Opportunities for Persons with Discapacity", approved by the UN General Assembly, and after a detailed assessment of the remedy to be granted, the Court ordered the creation of an inter-disciplinary professional team with representatives from different public entities from the national and district level, in order to undertake a rehabilitation process that could allow for the evaluation, within a reasonable term, of the blind woman's real capacity to provide for her daughter and allow her to grow up in a safe and adequate environment.

\subsection{National projection and enforcement of preventive measures adopted by the Inter- American Court of Human Rights}

Finally, it is pertinent to point out a relatively recent development: the reception of InterAmerican precautionary measures to protect persons at risk in urgent and serious cases. In such tutela decisions, the Constitutional Court has not only adopted the Inter-American legal doctrine, but also the specific orders imparted as remedies to render them effective.

The leading case in this field was a judgment, in which the Court reviewed the accion de tutela filed by the relatives of a human rights advocate who had been the victim of forced disappearance, against the Ministry of Foreign Affairs and the Ministry of the Interior. ${ }^{14}$ The plaintiffs had requested the Inter-American Commission on Human Rights to adopt the necessary measures to protect their fundamental right to life; and this body pres- 
ently ordered the Colombian State to implement the measures required to protect the lives, integrity and dignity of the members of the family. Nonetheless, Colombian State agents irrupted a few days later into the family's home, and they tortured one of its members. Even though the Inter-American commission had ordered the adoption of precautionary measures on two opportunities, the authorities had ignored such decisions. The Constitutional Court granted the tutela, and held that

"the tutela judge may issue an order directed at the public authority so that the latter protects a fundamental right whose threat or violation justified the adoption of a precautionary measure by the Inter-American Commission on Human Rights".

This same line was followed by the Court later on. ${ }^{15}$ In this case -brought to the Court collectively, and not individually-, some members of the San José de Apartadó Peace Community had presented the acción de tutela against a National Army Brigade Commander, arguing that their rights to life, personal integrity, security and others were being placed at risk by the military authorities, who were involved in acts of violence and persecution aimed at tarnishing their reputation or eliminating them. Prior to the presentation of the tutela lawsuit, the plaintiffs had requested the protection of the Inter-American Court of Human Rights, which ordered the adoption of certain precautionary measures aimed at safeguarding their rights - measures that had not been executed by the national authorities. The tutela was granted. The Court clarified that it would issue

"both the protective measures that correspond to the regional level, in accordance with the requirements of the Inter-American Court of Human Rights, and the orders that appertain to the tutela action brought to its decision".

In other words, through the channel of the acción de tutela, the Court not only ordered the adoption of the remedies required to preserve the fundamental rights invoked by the plaintiffs, but also imparted specific mandates to implement the precautionary measures which had been ordered by the Inter-American Court of Human Rights.

From these holdings, one should also underscore the facts that (a) the Court appropriated itself of the precautionary measure to the point of transcribing its literal content; (b) the Court transformed non-compliance with an Inter-American precautionary measure into the legal grounds for possible contempt of court proceedings at the national level; and (c) the Court specified which were the National authorities in charge of securing compliance with the precautionary measure, raising their level to the Ministerial ambit.

\section{Conclusion}

IHRL and IHL have borne a significant impact upon decisions concerning both the preservation and public order and the protection of rights in other contexts. 
Although the 1991 Colombian Constitution contains a very generous bill of rights, IHRL and IHL has been frequently incorporated in diverse types of settings, causing a very high material incidence upon the domestic legal system. Considerations that would initially have seemed to be closer to obiter dicta, have later come to be the clear foundations of the ratio decidendi of several recent judgments. In addition, Inter-American parameters have been decisive for the constitutional review of national legislation.

On the other hand, IHRL and IHL have been incorporated in very sensitive ambits of constitutional review, and in relation to very controversial issues in the Colombian contexts. They have served to support the legitimacy of the Constitutional Court's decisions. Nevertheless, it should be pointed out that in several of the more polemic decisions not mentioned in this note, such as the euthanasia case ${ }^{16}$ and the personal drug consumption case, ${ }^{17}$ IHRL and IHL did not play a significant function.

Moreover, this reception process forms part of a broader dialogue with other Courts which are equally committed to the defense of human dignity, the construction of peace through the Law and the preservation of democracy's foundations. 